\title{
多結晶体中における微視組織的微小表面き裂の応力拡大係数*
}

\author{
釜 谷昌 幸*1, 北 村 隆 行*2
}

\section{Stress Intensity Factors of Microstructurally Small Surface Crack in Polycrystalline Material}

\author{
Masayuki KAMAYA*3 and Takayuki KITAMURA \\ ${ }^{* 3}$ Institute of Nuclear Safety System, Inc., \\ 64 Sata, Mihama-cho, Mikata-gun, Fukui, 919-1205 Japan
}

\begin{abstract}
Avaraging the anisotropy of each crystal, the macroscopic behavior of polycrystalline materials is isotropic and homogenous in terms of elastic deformation. However, the anisotropic and/or inhomogeneous property influences on the stress field ahead of a crack if the crack size is small in comparison with the grain. This bring about the change in the stress intensity factor (SIF). In present study, in order to invistigate the cause and magnitude of the change in the SIF, the finite element analysis is performed. The calculations are carried out for the polycrystal cracked plate model, which consists of hexagonal pillar shape of crystal grains with random orientation. The results implied that the SIF of microstructurally small crack is greatly affected by the deformation constraint caused by the difference in elastic modulus of grains near the crack. The statistical scatter of SIF due to the random orientation of crystal orientation in a polycrystal is examined by a Monte Carlo simulation. The variation in the SIF becomes large as the crack size decreases and anisotropy of the material increases. We propose an equation for estimating the variation in the SIF of the microstructurally small crack.
\end{abstract}

Key Words: Stress Intensity Factor, Finite Element Method, Small Crack, Polycrystal, Anisotropic Elasticity, Microstructure, Constraint

\section{1. 粕}

疲労や応力腐食割れ (Stress Corrsion Cracking, 以 後 SCC) などではき裂進展速度と応力拡大倸数（K 值) との間に相関関係のあることが経験的に示されて いる(0)，K值はハンドブッククどを用いることで 多様なき裂形状や境界条件に対する值を求めることが できる. したがって，試験によりこの相関係数を調べ ておけば，き裂の進展を予測することが可能となる.

これまで，このようなK值に基づくき裂進展予測が工 業的に広く行われてきたに》。

しかし，従来の解析では，材料が均質等方弾性 体であるという仮定のもとで求められたK值を用いて いた. 多絬晶体は，巨視的には耐力以下で等方弾性体 とみなすことができるが，微視的にはそれぞれの絬晶 粒は弾性恭方性を有している. そのため, き裂サイズ が絬晶粒径と同じオーダーの微小き裂においては, 絬 晶粒の弾性異方性がき裂周囲の応力場に及ぼす影響は 無視できなくなる．弾性異方性を有する単絬晶中のき

* 原稿受付 2005 年 5 月 13 日.

*1 正員, (株)原子力安全システム研究所 (-919-1205 福井県 三方郡美浜町佐田 64).

*2 正員, 京都大学大学院工学研究科( $\mathbf{\infty} 606-8501$ 京都市左京 区吉田本町).

E-mail : kamaya (a inss.co.jp
裂では，結晶方位に依存してK值が変化することが指 摘されている89.また, 多結晶体中では, き裂が存 在しない場合でも結晶粒同士の変形拘束の影響により, 応力分价が不均一になることが示されており (10011), き 裂が存在する場合にもK值はその効果により変化する と考えられる. したがって, これらの影響を考慮して 算出された微小き裂のK值（以後，ミクロなK值と呼 ぶ) は, 同じ形状の一様等方弾性体条件下で評価され たK值（以後，マクロなK值と呼ぶ）とは異なる(邓． そして, これが不規則で不安定な進展速度に代表され る微小き裂の特異な進展挙動 (32(2)の要因の一つであ ると考えられる.

本研究では, 多結晶体表面にある半円形表面き 裂のミクロなK值を有限要素法により解析し，K值の 変化をもたらす要因と，その変化の大きさについて考 察する. まず，多結晶体を構成する結晶粒の基本とな る単結晶モデルを用いて, 単結晶中に存在する半円き 裂のK值の結晶方位による変化を調べる. 次に, 多絬 晶体を模擬したモデルを用いて, 多結晶中におけるミ クロなK值の変化の傾向について考察する. とくに, 隣接する結晶粒による変形拘束の影響に着目し, 多結 晶体中のミクロなK值がマクロなK值と異なる要因に 


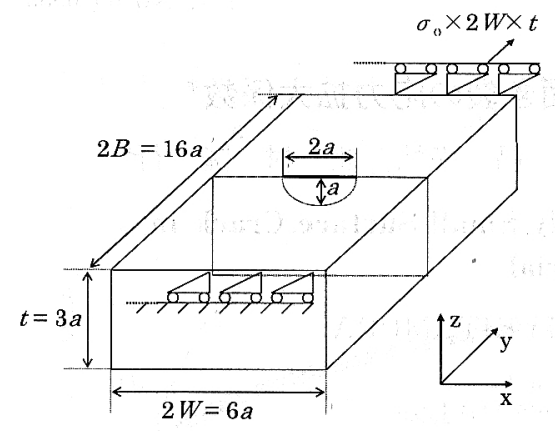

Fig.1 Analysis model of plate with a semi-circular surface crack under tension.

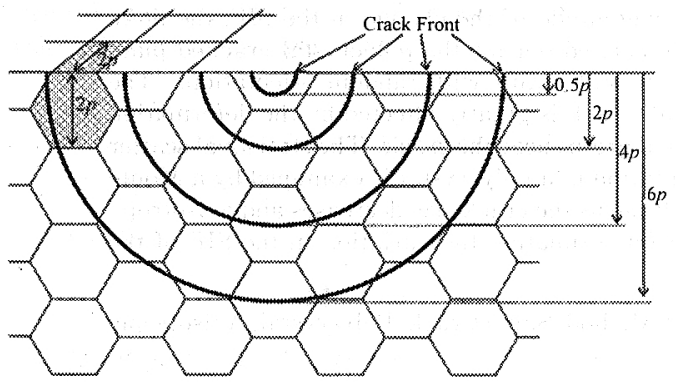

Fig.2 Crack size in the polycrystal model

つい考察する.また，微小な SCC き裂の進展を統 計的に予測するために(2)，結晶方位をランダムに与え た場合のミクロなK值の統計的な変化を調べた.

\section{2. 解析方法}

解析対象は，図 1 に示探さ $a$ の半円形表面き裂 を中央部に導入した平板である. 平板のサイズは，幅 $W=3 a$ ，厚さ $t=3 a$ ，長さ $B=8 a$ で，遠方一様引張灾 力 $\sigma_{0}$ を負荷した. 平板は 6 角柱 (ただし, 自由境界 と接する部分を除く）の結晶粒で構成されており，結 晶粒に対するき裂の相対サイズを図 2 に示す 4 種類設 定した. つまり，結晶粒を代表するサイズ $p$ を基淮に， き裂サイズを $0.5 p ， 2 p ４ p$ ，そして $6 p$ とした．以後， これらのき裂サイズに対応したモデルを，それぞれ $0.5 p$ モデル, $2 p$ モデル, $4 p$ モデル, そして $6 p$ モデル と呼ぶ：それぞれのき裂サイズの場合のき裂面断面に おける有限要素メッシュを図 3 に示す。この図におい て，結晶粒は濃淡によって区別した，それぞれのモデ ルから得られたK值を比較するために，き裂と平板の 相対サイズを一定とした．図 4 に $0.5 p$ モデルの全体 図を示すが，いずれのモデルにおいても結晶粒の長手 方向は荷重方向に平行で，その端面は荷重方向に垂直

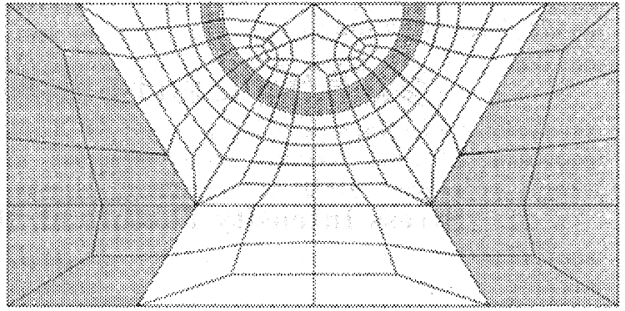

(a) $0.5 p$-cracked polycrystal model

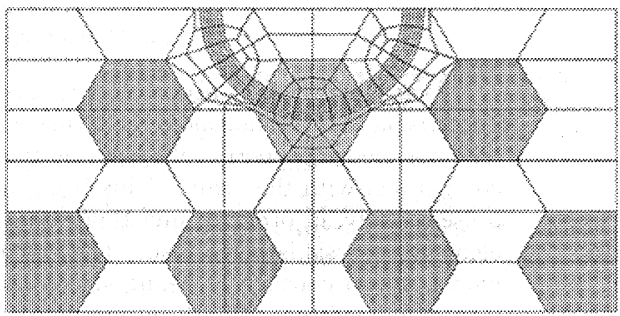

(b) $2 p$-cracked polycrystal model

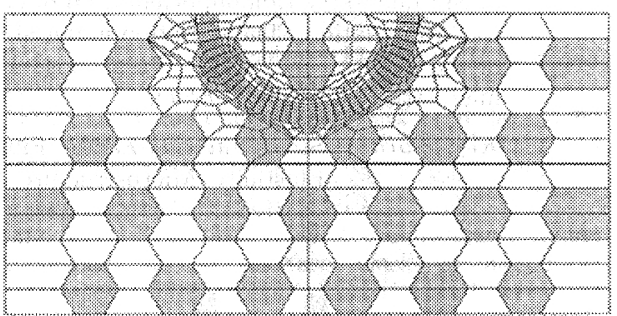

(c) $4 p$-cracked polycrystal model

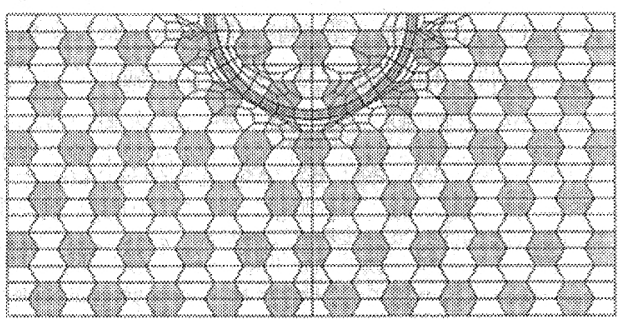

(d) $6 p$-cracked polycrystal model

Fig. 3 Sectional view of finite element mesh divisions for polycrystal models.

な面である.き裂面は何重方向に垂直に，平板の長手 方向の中央部，つまり図中に示した Grain1 の結晶粒 内にある.それぞれの有限要素メッシュを用いてマク 口なK值を評価した結果を図 5 に示す。ここで，K值 は次式で無次元化している.

$$
F_{1}=\frac{K_{\mathrm{I}}}{\sigma_{0} \sqrt{\pi a}}
$$

これらの結果は, 表面点を除いて同じ境界条件で算出 した高精度な解析結果(2)とよく一致している。 したが 
って, 図 3 に示した有限要素メッシュにより精度の高 い解析が可能である. 結晶粒の弾性定数は表 1 に示し た $\mathrm{Ni} ＼textrm{A l} ， \mathrm{Cu} ， \mathrm{Fe}$ そしてWのものを用いた(24. 解析 では，それぞれの結晶粒の結晶方位を一様乱数で与え， 400 通りの結晶方位の組み合わせに対してK值を求め たモモデルの対称性は考慮せず，全ての結晶粒に対し て別々の方位を与えた，単結晶に対する解析も実施し， その場合は $0.5 p$ モデルにおいて全ての結晶粒の方位 を同一に設定した単結晶モデルを用いた，有限要素解 析には，汎用の有限要素解析コードである ABAQUS

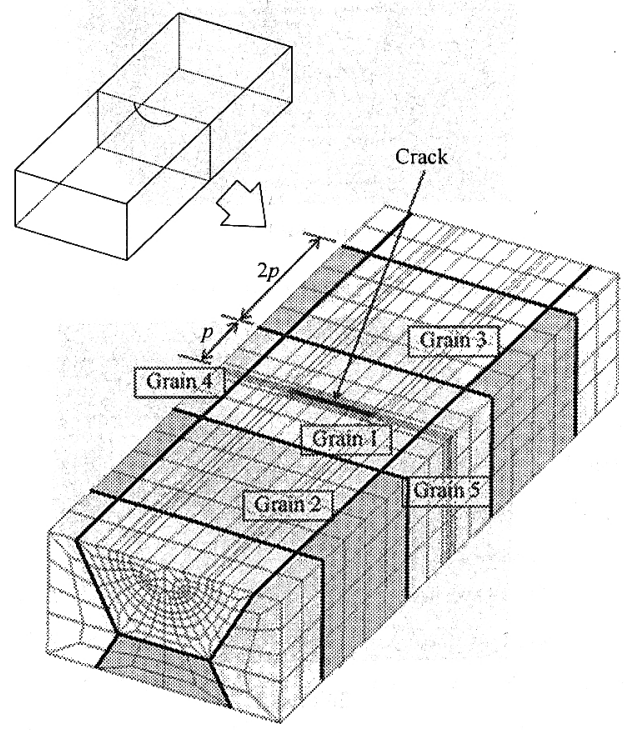

Fig.4 Crack position in polycrystal model ( $0.5 p$ - cracked polycrstal model).

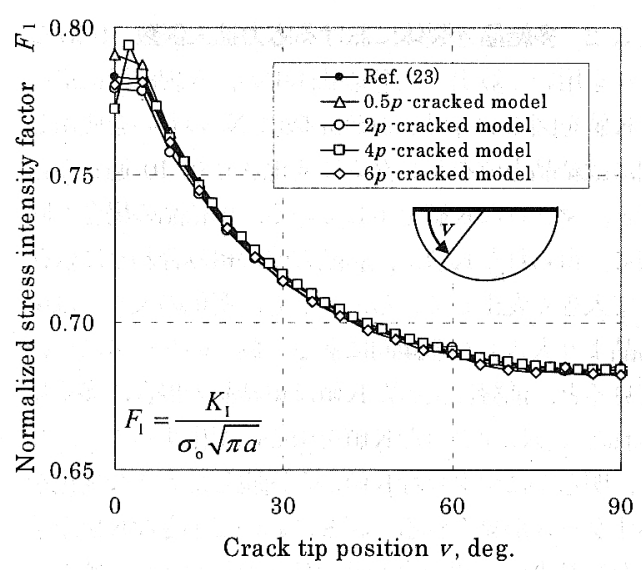

Fig.5 Stress intensity foctor evaluated using the polycrystal models in homogenous body.
Ver.6.3(ð)を用いた.このコードでK值は仮想き裂進展 法で求めた J積分值から算出される。的。

Table 1 Elastic compliance of materials.

\begin{tabular}{|c|c|c|c|}
\hline \multirow{2}{*}{ Material } & \multicolumn{3}{|c|}{ Elastic compliance $\left(10^{-11} \mathrm{~Pa}^{-1}\right)$} \\
\cline { 2 - 4 } & $S_{11}$ & $S_{12}$ & $S_{44}$ \\
\hline $\mathrm{Ni}$ & 0.73 & -0.27 & 0.80 \\
\hline $\mathrm{Al}$ & 1.57 & -0.57 & 3.51 \\
\hline $\mathrm{Cu}$ & 1.50 & -0.63 & 1.33 \\
\hline $\mathrm{Fe}$ & 0.80 & -0.28 & 0.86 \\
\hline $\mathrm{W}$ & 0.26 & -0.07 & 0.66 \\
\hline
\end{tabular}

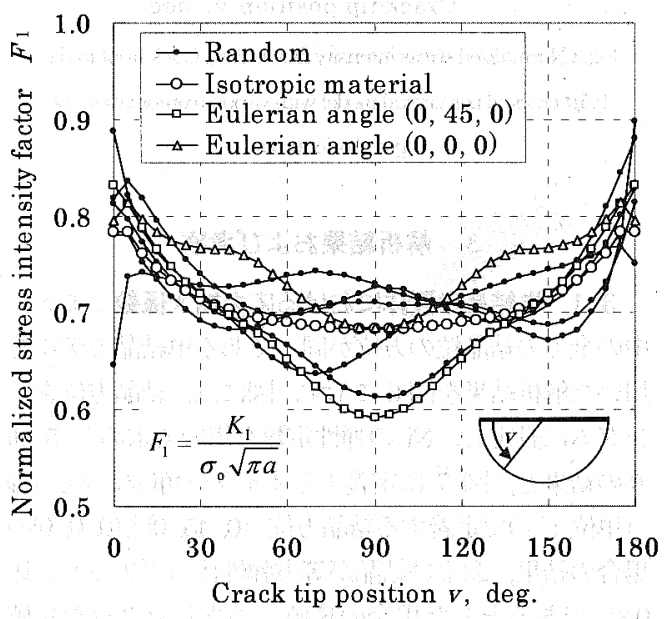

Fig.6 Normalized stress intensity factor along crack front in single crystal model with various crystal orientations.

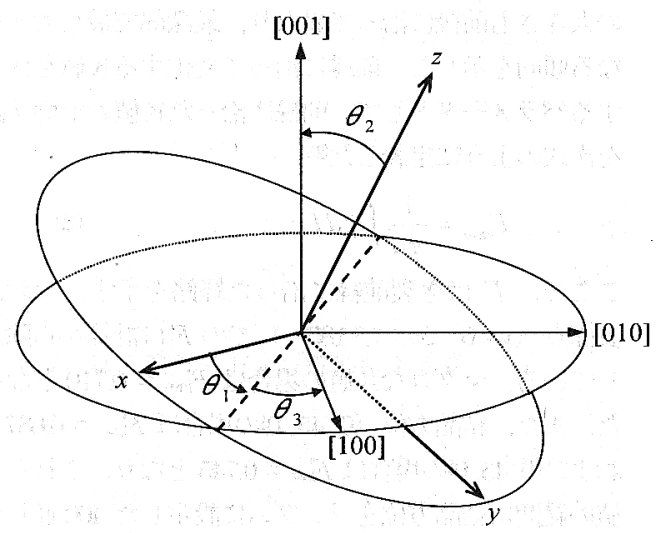

Fig.7 Eulerian angles between the crystal coordinates and the xyz-coordinates. 


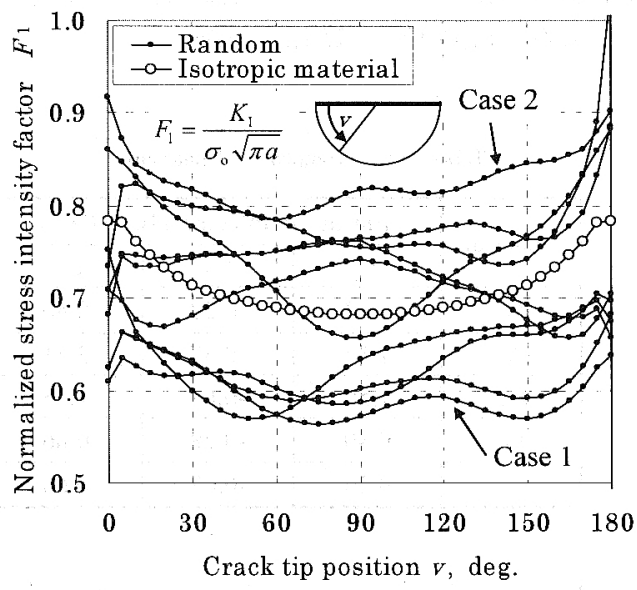

Fig.8 Normalized stress intensity factor along crack front in the $0.5 p$-cracked polycrystal model with various combinations of crystal orientation.

\section{3. 解析結果および考察}

3.1 単結晶き裂体における応力拡大係数 モデル 中の全ての結晶粒の方位が同一である単結晶モデルを 用いた解析結果を図6に示す，図には，結晶方位をラ ンダムに設定し， Ni の弾性定数を用いて求めた 5 通 りの結果と, 図 7 に定義するオイラー角 $\left(\theta_{1}, \theta_{2}, \theta_{3}\right)$ (単位：ㅇ.)で定義する結晶方位 $(0,45,0)\llcorner(0,0,0)$ の 場合の結果, およで結晶が等方弾性体 (ポアッソン比 0.3）であるとした場合のK值，つまりマクロなK值 も示した：これまでに指摘されてきたように(80)，単 結晶中の半円表面き裂のK值は，結晶方位に依存して マクロなK值とは異なった值となる，また，その変化 の大きさも前縁に沿って異なり，最深部で最も大きく なる傾向を示した，前縁に沿って変化するK值を代表 するパラメータとして, 前縁に沿ったK值の平均 $F_{\text {law }}$ を次式のように定義した22。.

$$
F_{\text {lave }}=\frac{1}{\pi a} \int F_{1} d \Gamma
$$

ここで，「はき裂前縁に沿った経路を示す，なお， 表面点（ している. マクロなK值の場合は $F_{\text {law }}=0.710$ となっ た. また，結晶方位 $(0,45,0)$ の場合は $F_{\text {lae }}=0.687$, および $(0,45,0)$ の場合は $F_{\text {lave }}=0.745$ となり，これらの 值の範井に結晶方位をランダムに設定した 400 通りの $F_{\text {laæ }}$ の全てが含まれた。このことから，単結晶中の応 力搪大係数 $F_{\text {lave }}$ は，0.687 から 0.745 の範用で変化す ると考えられる。
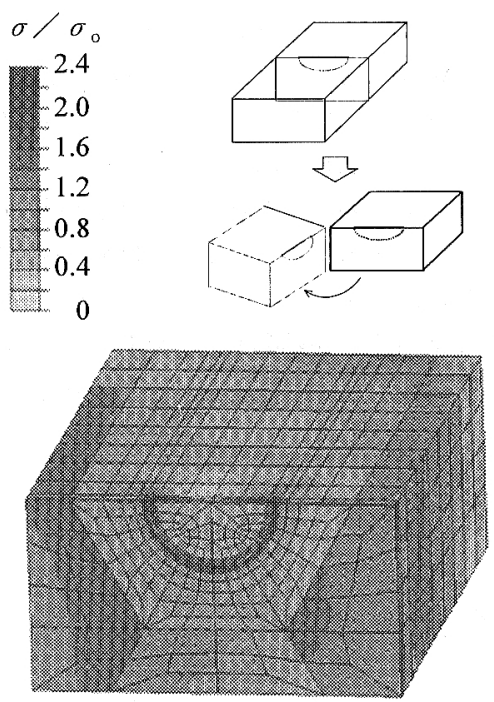

(a) Case 1

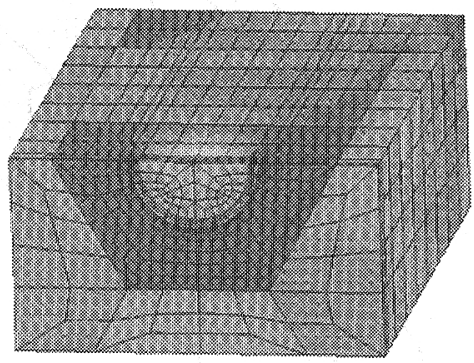

(b) Case 2

Fig.9 Normalized stress in $0.5 p$-cracked polycrystal models obtained by finite element analysis.

3.2 多結晶き裂体における応力拡大係数 $0.5 p$ モ デルを用いて算出した多結晶体中の，き裂前縁に沿つ たK值を図 8 に示寸。弾性定数は $\mathrm{Ni}$ のものを使用し， 図には結晶方位をランダムに変化させた 10 通りの結 果と，マクロなK值を示している. 単結晶の場合と同 様に，得られたK值は，結晶方位の組み合わせに依存 して大きく変化している. しかも，変化の大きさは単 結晶より大きくなる傾向にある．個々のケースについ て見ると，前縁に浻ったK值は単結晶の場合に多く見 られたようにマクロなK值を中心に変化するのではな く，明らかにマクロなK值から逸脱した大きな変化を 示すケースが見られる. 図8において小さなK值を示 した結晶方位の組み合わせ（Case1）と大きなK值を示 した組み合わせ（Case2)について，き裂部分周囲の Mises 応力分布を図 9 に示寸，いずれのケースも，き 


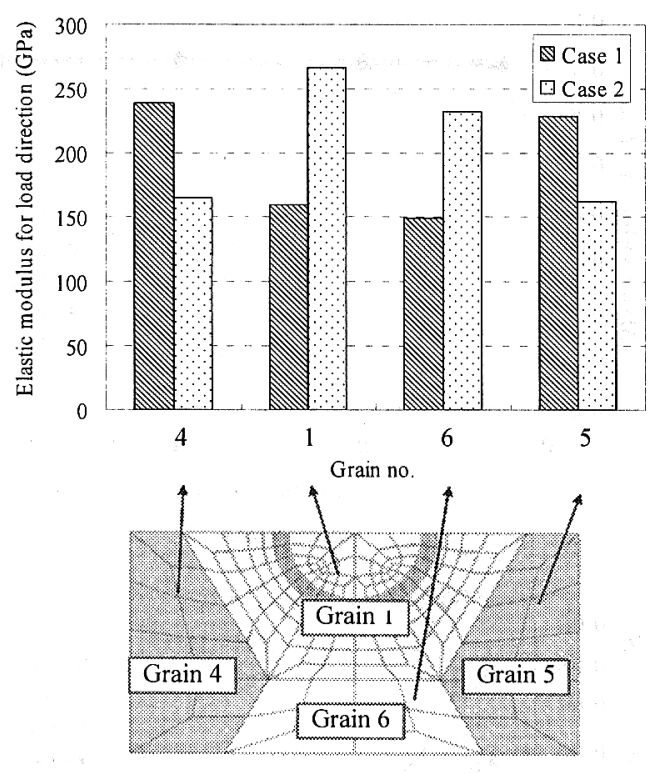

Fig.10 Elastic modulus along loading direction.

裂前縁に沿って応力が集中している様子が見られる. また，き裂が存在する中心部分の結晶粒の忘力を見る と, K值の小さい Case1 の方が，K值の大きい Case2 より大きくなっていることが分かる.このような結晶 粒每の不均一な䄈力分布の影響により, Casel および Case2 のK值は，前縁全体に渡ってマク口なK值より 大きくシフトしたと考えられる. Case1 と Case2 にお ける，き裂周囲の結晶粒の応力方向に対する等価弾性 率を図 10 に示す. Case1 においては，き裂の存在す る結晶粒の弾性率が周囲のそれより小さくなっている. これにより，き裂の存在する結晶粒の応力が相刘的に 小さくなったと考元られる. 逆に, Case2 においては き裂の存在する絬晶粒の弾性率が相対的に大きくなり， 周囲の絬晶粒よりも分担寸る荷重が大きくなった。 まり, き裂周囲の結晶粒の相対的な弾性率が応力分布 に影響している. 例えば，図 4 で定義したき裂が存在 する結晶粒 Grain1 と隣接する結晶粒 Grain2 および Grain3 の方位を $(35.3,45.0,0.0)$ （\{111\}面を応力方向に 垂直に向けた場合に相当) とし，他の結晶方位を $(0,0$, 0)とした場合についてK值を計算すると $F_{\text {laxe }}=0.988$ と大きな值となる．また，逆に Grain1,2,3 の方位を(0, $0,0)$ とし，他を(35.3, 45.0,0.0) とした場合は， $F_{\text {lave }}=$ 0.435 と小さな值となった. 同様に Grain1 のみの方位 を他の結晶粒と異なるように設定した場合は，それぞ れ $F_{\text {laxe }}=0.789$ および 0.695 となり, 先の場合より変化 の幅は小さくなる.このように, 多絬晶体においては,

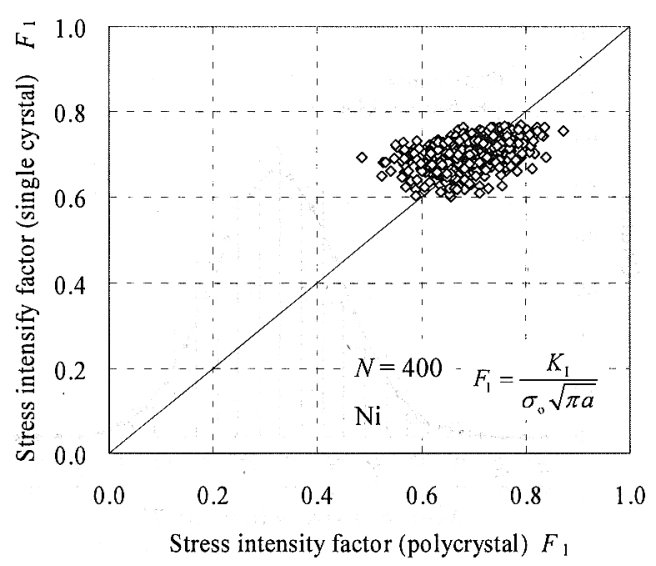

(a) Relation between $F_{1}$ in polycrystal model and $F_{1}$ in single crystal model with the orientation of Grain 1

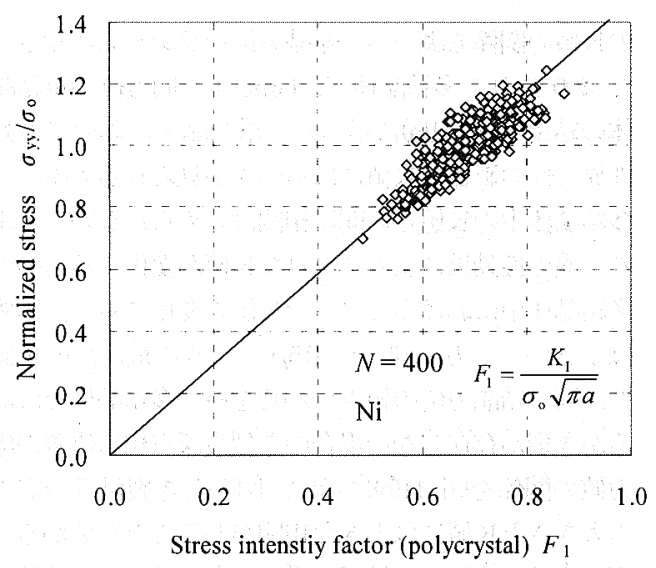

(b) Relation between $F_{1}$ in polycrystal model with a crack and normalized stress at the correspondent point of the deepest crack front in the model without a crack.

Fig.11 Influenoe of anisotropic elasticity and constraint on stress intensity factor in polycrystalline material.

周囲の結晶粒との弾性率の関倸，つまり結晶方位の関 倸により荷重の分担が変化し，それによってその結晶 粒に存在するき裂のK值が变化する。

3. 3 異方性効果および変形拘束効果 以上のよう に, 多結晶体中のミク口なK值の変化をむたらす要因 として, 弾性異方性の影響 (以後, 異方性効果と呼 ぶ）と，周囲との等価弾性率の差に起因する結晶粒の 変形拘束の影響 (以後, 変形拘束効果) が考えられる. これらの内，異方性効果の影響を考察するために， $0.5 p$ モデルの最深点のK值と，き裂が存在する結晶粒 Grain 1 と同じ方位の単結晶モデルにおける最深点で 


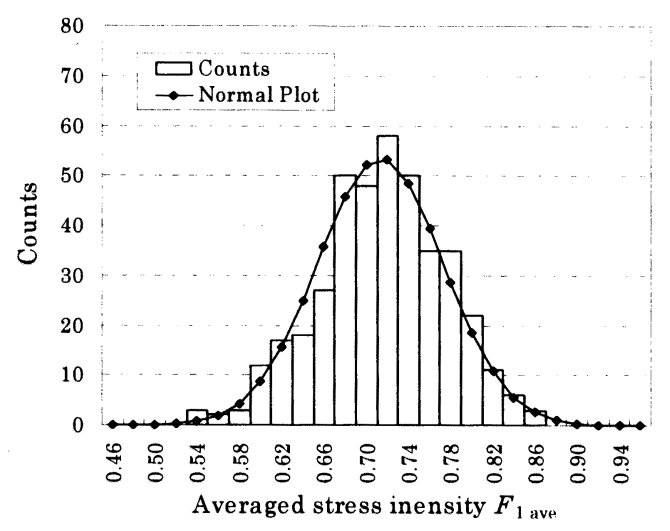

Fig.12 Distribution of averaged $F_{1}$ along the crack front

$(0.5 p$-cracked polycrystal model, $N=400$, crystal orientations are random)

のK值の関係を調べる. 結晶方位をランダムに設定し た 400 通りの多結晶体と, Grain 1 と同方位の単結晶 体の結果を図 11(@)に示した. 単結晶中においても弾 性異方性の影響でK值にばらつきが見られるものの， 多結晶体中のK值との間に相関は認められない，つま り，異方性効果によりミクロなK值が変化するものの， 多結晶体中におけるミクロなK値の変化に対する影響 は小さい. 一方, 同じく $0.5 p$ モデルの最深点のK値 と, 同じ結晶方位の組み合わせを持つ多結晶体ではあ るがき裂が存在しない場合のき裂最深点相当位置の応 力值の関係を図 11(b)に示寸. 図からき裂付近の応力 の大きさとK值には大きな相関があることが分かる.

図 9 およひ図 10 の結果と併せて考えると, 多結晶体 中におけるミクロなK值の変化には変形拘束効果が大 きく奇与している. 図 11(b)に示した直線は, 図 8 に 示したマクロなK值の最深点の值 $F_{1}=0.683$ と無次元 化応力 $\sigma_{\mathrm{y}} / \sigma_{0}=1$ の交点と原点を結んだ直線を示して いる.この直線とミクロなK值の，関係から，き裂のな いモデルを用いてき裂部分の応力を解析することで, 多結晶体中におけるミクロなK值を推測することが概 ね可能であることが分かる.

\section{3. $4 \mathrm{~K}$ 值变化の統的㑯向 多結晶体中のミク} 口なK值の変化は, 変形拘束効果の影響が支配的であ ることが明らかになったが, 変形拘束による応力変化 を結晶方位の組み合わせから解析的に導くことは困難 である. そこで, 多結晶体の結晶方位がランダムであ ると仮定して, ランダムに与えた結晶方位からK值の 変化の統計的な傾向を考察する. $\mathrm{Ni}$ の弾性定数を用 いた $0.5 p$ モデルから得られる $F_{\text {laxe }}$ の分布を図 12 に示 す. 結晶方位の組み合わせによって $F_{\text {law }}$ はばらつく

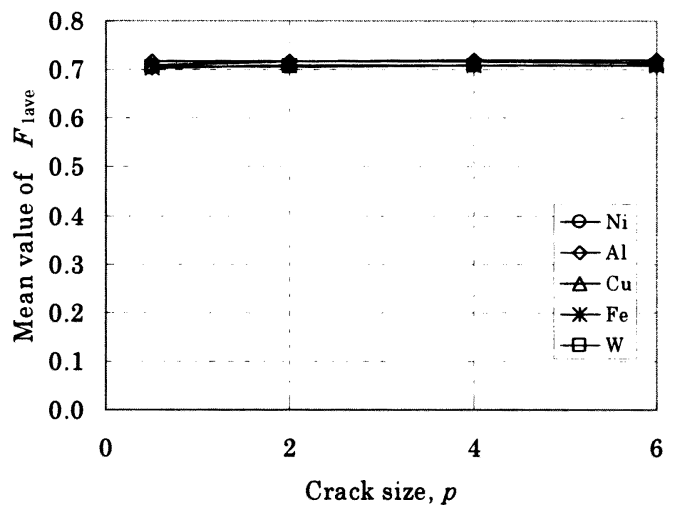

(a) Mean value

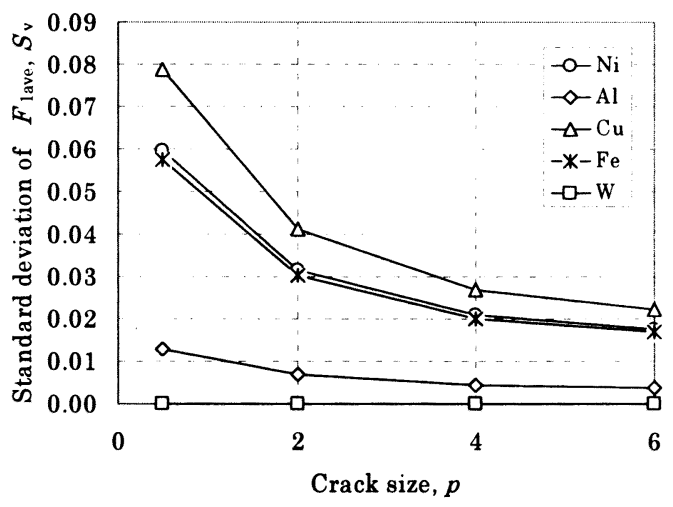

(b) Standard deviation

Fig.13 Change in the distribution parameters for the crack size $(N=400$, crystal orientations are random).

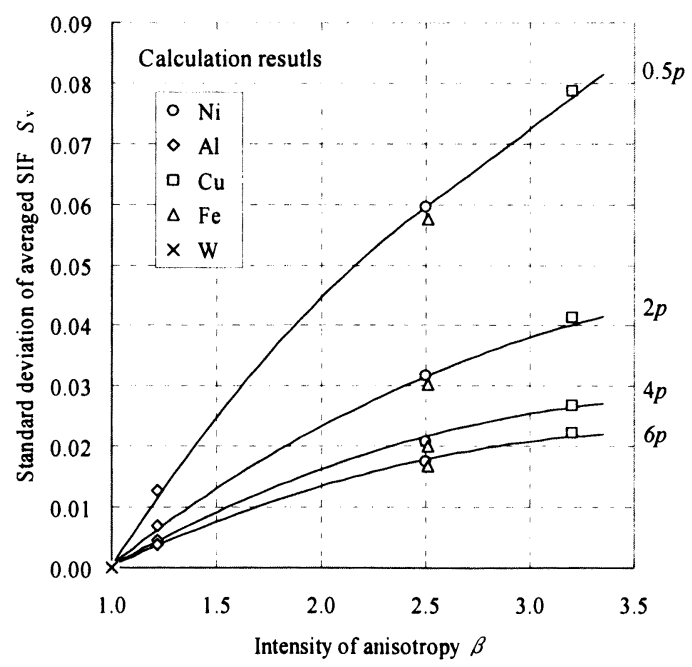

Fig.14 Relationship between degree of anisotropy and variation in the stress intensity factor. 
きは小さく，巨視的なき裂のK値と同等になる.

計算ではモードாおよびモード III のK值も算出さ れた. $0.5 p$ モデルで $\mathrm{Ni}$ の場合, (2)式と同様に計算し たモード II およびモード III のK值の最大值はそれぞ れ 0.37 と 0.65 で, モード I のK值と比較して小さい.

3.5 材料の清 図13(b)に示寸ように, $F_{\text {laee }}$ の 平均は材料，き裂サイズによらずほぼ一定であるが、 標準偏差は材料によって買なる. 異方性の小さい W でK值のばらつきはほとんど見られないが，異方性の 大きい $\mathrm{Cu}$ の標淮偏差は最も大きい. これは, 弾性異 方性が大きくなることで, 多結晶体中での応力分布の 不均一性が増加し，K值の標準偏差が大きくなったた めと考えられる. 図 13 の結果から, 異方性の大きさ $\beta$, き裂サイズ $p$ および $F_{\text {lax }}$ の標準偏差 $S$ との関係 を近以し, 次式を得た，

$$
\begin{aligned}
S_{\mathrm{v}} & =\left(-0.00458 \beta^{2}+0.0344 \beta-0.0293\right) e^{\frac{-p-0.5}{14.0}} \\
& +(0.0276 \beta-0.0282) e^{\frac{-p-0.5}{0.374 \beta+1.27}} \\
& +(0.0522 \beta-0.0525) e^{\frac{-p-0.5}{1.1}} \\
\text { ここで, } \beta \text { は次式で与えられる } & \quad \beta=\frac{2\left(S_{11}-S_{12}\right)}{S_{44}} .
\end{aligned}
$$

図 14 に(3)式の関係と, 図 13 の計算絬果を併せて示寸. $\beta=1$ となるW では標準偏差はほとんど 0であるが, $\beta$ が増加するにしたがって標準偏差も大きくなり， $\beta$ と標準偏差はよい相関関係を示している. これより， 材料の弾性異方性とき裂サイズから(3)式を用いて多絬 晶体中のミクロなK值の統計的な変化を推測できる(2).

\section{4. 結}

単絬晶モデル, き裂サイズの異なる 4 種の多結晶 モデルを用いて, ミクロなK值について解析し, 以下 の結論を得た.

1) 単結晶中のミクロなK值は, 絬晶方位に依存す る. その変化幅は, き裂前縁に沿った無次元化 $\mathrm{K}$ 値の平圴 $F_{\text {læe }}$ で 0.687 から 0.745 の間であると考え られる。

2)多結晶き裂体のミクロなK值は, 結晶方位の組 み合わせによって単結晶中より大きな変化を示し た. それは, 多結晶体中の応力の不均一な分布が 要因である.
3） ランダムな結晶方位の多結晶き裂体のミクロな $\mathrm{K}$ 值は正規分布にしたがう. その平均值は材料, き裂サイズに依存することなく, マクロなK值と ほぼ同一である. 一方, 標準偏差はき裂サイズが 小さくなるほど, また材料の弾性異方性が大きく なるほど, 大きくなる.

4)き裂サイズと材料の弾性異方性よりミクロなK 值分布の標淮偏差を求める近似式を得た.

\section{文献}

(1) Paris, P.C. and Erdogan, F., A Critical Analysis of Crack Propagation Laws, Transaction of the ASMESer. D85, 528 (1963), 528-534.

(2) Data Book on Fatigue Crack Growth Rates of Metallic Materials, (1983), The Society of Materials Science, Japan.

(3) Shack, W. J. and Kassner, T. F., Review of Environmental Effects on Fatigue Crack Growth of Austenitic Stainless Steels, NUREG/CR-617G, (1994).

(4) Y. Murakami(Eds), Stress Intensity Factors Handbook, (1987), Pergamon Press.

(5) Tada, H., Paris, P. C. and Irwin, G. R. The Stress Analysis of Cracks Handbook, Third Edition, (2000), ASME Press.

(6) Boiler \& Pressure Vessel Code Section XI 2002 Addenda, (2002), ASME.

(7) Fitness-for-Service Code, JSME SNA 1-2002 (2002), Maruzen

(8) Hashimoto, K, Sakane, M. and Ohnami, M, Stress Intensity Factor for Semicircular Surface Crack Embedded in Si Single Crystal, Nihon Kikai Gakkai Ronbunshu, A (Transactions of the Japan Society of Mechanical Engineers, Series A, 60-370 (1994), 317-323.

(9) Hashimoto, K, Sakane, M and Ohnami, M., Stress Intensity Factor for Cubic Single Crystal of Cu, Ni, Si, Al, and W, Nihon Kikai Gakkai Ronbunshu, A (Transactions of the Japan Society af Mechanical Engineers, Series A), 61-586 (1995), 1218-1224.

(10) Kitamura, T., Sumigawa, T. and Ohishi, K. Slip Behavior and Local Stress near Grain Boundary in High-Cycle Fatigue of Copper Polycrystal, JSME International Journal, Series A, 47-2, 92(2004), 92-97.

(11) Sumigawa, T. and Kitamura, T., Nucleation of Slip Bands near Twin Boundary in High-Cycle Fatigue, JSME International Journal, Series A, 47-2, (2004), 98-105.

(12) Kamaya, M. and Kitamura, T., Stress Intensity Factors of Microstructurally Small Crack, International Journal of Fracture, 124, (2003), 201-213. 
(13) Kitamura, T. and Ohtani, R., Creep Life Prediction Based on Stochastic Model of Microstructurally Short Crack Growth, Journal of Engineering Materials and Technology, 111, (1989), 169-175.

(14) Tanaka, K, Mechanics and Micromechanics of Fatigue Crack Propagation, Fracture Mechanics:Perspectives and Direction, ASTMSTP 1020, (1989), 151-183.

(15) Navarro, A and Rios, E. R., A Microstructurally-Short Fatigue Crack Growth Equation, Fatigue and Fracture of Engineering Materials and Structures, 11, (1988), 383-396.

(16) Wang, Y. Z., Ebtehaj, K, Hardie, D. and Parkins, R. N., The Behaviour of Multiple Stress Corrosion Cracks in a Mn-Cr and a Ni-Cr-Mo-VSteel, Corrasion Science, 37, (1995), 16511675.

(17) Pearson, S., Initiation of Fatigue Cracks in Commencial Aluminum Alloys and the Subsequent Propagation of Very Short Cracks, Engineering Fracture Mechanics, 7, (1975), 235247.

(18) Taylor, D. and Knott, J. F., Fatigue Crack Propagation Behaviour of Short Cracks, Fatigue and Fracture of Engineering Materials and Structures 4, (1981), 147-155.

(19) Tokaji, $\mathrm{K}$ and Ogawa, T., The Growth Behaviour of Microstructurally Small Fatigue Cracks in Metals, Short Fatigue Cracks, ESIS 13, (1992), 85-99, Mechanical Engineering Publications.
(20) Miller, K J., The Behaviour of Short Fatigue Cracks and Their Initiation, Fatigue and Fracture of Engineering Materials and Structures, 10, (1987), 75-91.

(21) Moevily, A J., The Growth of Short Fatigue Cracks, Materials Science Research International 4, (1998), 3-11.

(22) Kamaya, M and Kitamura, T., A Simulation on Growth of Multiple Small Cracks under Stress Corrosion, International Journal of Fracture, 130, (2004), 787-801.

(23) Kamaya, M. and Kitamura, T., Stress Intensity Factors of Interacting Parallel Surface Cracks, Nihon Kikai Gakkai Ronbunshu, A (Transactions of the Japan Society of Mechanical Engineers, Series A) 68-671, (2002), 114-121.

(24) Ngashima, S., Shugou Soshiki, (1984), 262, Maruzen (in Japanese).

(25) ABAQUSSTtandard User's Manual Version 6.3, (2002), ABAQUS. Inc.

(26) Shih, C. F. and Asaro, R. J. Elastic-Plastic Analysis of Cracks on Bimaterial Interfaces, Journal of Applied Mechanics, 55, (1988), $299-316$.

(27) Kamaya, M, Stress Intensity Factors of Surface Crack with Undulated Front, International Journal of Fracture, to be published. 